\title{
Balkanologie
}

Balkanologie Revue d'études pluridisciplinaires

Vol. V, no 1-2 | 2001

Volume V Numéro 1-2

\section{Memories of Anatolia : generating Greek refugee identity}

Alice James

\section{OpenEdition}

1 Journals

Édition électronique

URL : http://journals.openedition.org/balkanologie/720

DOI : $10.4000 /$ balkanologie. 720

ISSN : 1965-0582

Éditeur

Association française d'études sur les Balkans (Afebalk)

Édition imprimée

Date de publication : 31 décembre 2001

ISSN : 1279-7952

\section{Référence électronique}

Alice James, « Memories of Anatolia : generating Greek refugee identity », Balkanologie [En ligne], Vol. V, $n^{\circ}$ 1-2 | 2001, mis en ligne le 02 juin 2008, consulté le 17 décembre 2020. URL : http://

journals.openedition.org/balkanologie/720; DOI : https://doi.org/10.4000/balkanologie.720

Ce document a été généré automatiquement le 17 décembre 2020.

(c) Tous droits réservés 


\title{
Memories of Anatolia : generating Greek refugee identity
}

\author{
Alice James
}

The experience of the Asia Minor Greeks merits special attention, since it provides a unique, long-term case-study of adjustment and settlement in both rural and urban areas. Understanding social life in such localities may provide insights into some ways in which uprooted people cope with the challenges of survival, with material deprivation, with social and personal disruption and with the issue of identity. ${ }^{1}$

Greeks who fled from Asia Minor after 1922 and their descendants created a refugee identity that they have used as a strategy to cope with the trauma of forced displacement. Their memories of their lost homeland of Anatolia have played a major role in establishing their separate status as a refugee group within a population with the same language and religion.

2 All journeys between times, statuses, and places require interpretation to create a meaningful experience. Memories have helped to translate the refugees' journey and give shape to the imagined community of Mikrasiates (Greek people from Asia Minor). The impact of memory has aided the refugees in the social construction of a common public and private identity.

3 The loss of their homeland might have led to loss of identity, but instead these refugees used the catastrophe of traumatic emigration to give profound emotional legitimacy to their existence as a people. Using memory as a tool, this displaced population created an imagined community of Mikrasiates attached to remembered and enhanced places of their homeland-the lost paradise of Anatolia. Once reproduced in art and artifact, the remembered places and the imagined community could be modeled, adapted, and transformed to give meaning to social life in the new location, Greece. The enhancement of Anatolia emphasizes the importance of real and ideal memories in laying a claim to a homeland and in the creation of a social identity as a people.

Recollections passed down through families of large estates and comfortable lives have been used to highlight the disparity between their past wealth in Anatolia and the deprivation that they have suffered as impoverished victims of "ethnic cleansing". Many Asia Minor refugees escaped from their homeland with only memories of their 
former lives. Reports, such as those of Smyrna burning and the overcrowded, impoverished conditions on refugee ships and in camps in Greece, impelled the international community to mobilize aid.

5 Currently, remembrance is are enhanced by visual representations such as displays in museums, icons from Asia Minor in churches, collections of photographs in books, and exhibitions of film and photographs at city halls in areas settled by refugees. These visual images continue to propagate the memories that are used in the construction of a separate refugee identity.

The refugee experience and the construction of identity by the Asia Minor Greeks deserve special attention. Although it has been since the early 1920s that they were forcibly expelled from their homeland, yet they have survived as a community within a larger population with the same language and religion. It is possible to follow the social production of the Mikrasiates' identity through four generations.

\section{Historical Background}

The Asia Minor Greeks were just one group of refugees in the Balkans in the first quarter of the twentieth century. Indeed, since the Ottoman Empire began to decline in the eighteenth century, and especially during its territorial collapse in the nineteenth and early twentieth centuries, many refugee groups, both Moslem and Christian, fled to escape the repression that accompanied the shift in the governing of territories.

Under the Ottoman Empire the various linguistic, ethnic, and religious groups had lived intermixed, often with their own community administrative jurisdiction by millet, under the control of the central Ottoman government ${ }^{2}$. During the nineteenth century, national movements gradually broke apart the old Ottoman Empire; the Greek national movement was the first, in 1832, to achieve full independence. The national independence movement in Greece caused much uprooting of local populations. A famous incident that mobilized Western European support for Greek sovereignty took place in the eastern Aegean on the island of Chios, the site of my field study. In reprisal for rebellion by local islanders, probably due to encouragement from Greek revolutionary agitators from the neighboring island of Samos, the Ottomans devastated this previously privileged island. They massacred 20000 people, mostly men, and enslaved another 40000 , mostly women and children. A few thousand Chiotes escaped and founded refugee communities in London, Trieste, and Marseilles.

By the beginning of the First World War, on the European mainland only eastern Thrace was still Ottoman; the Russian and Austro-Hungarian Empires had increased their territories at the expense of the Ottomans. Over several centuries before that, responding to conflicts and border changes, refugees had moved across the Balkans. In 1690, for example, the Serbian Patriarch led tens of thousands Orthodox Christians north into Austrian territory, while almost two centuries later, a Russian offensive and the creation of a Bulgarian state sent Muslims streaming south and west into Anatolia and Macedonia. Such disordered migrations, motivated by fear, occurred again after the Greco-Turkish War of 1897 and the Balkan Conflicts of 1912-1913.

According to an international commission sponsored by the Carnegie Endowment in 1914, when the Balkan War fighting ceased, Greece had a population of 2,6 million, and 157000 refugees. By creating yet more refugees, the Ottoman Empire pressured Greece 
to negotiate a treaty. They deported 150000 Greeks from the Aegean coast of western Anatolia, and marched 50000 more into the interior ${ }^{3}$. These refugees included people who had not been disturbed by the fighting of the Balkan War. Elsewhere in his study, Marrus holds that the treaty mandating the uprooting of peaceful populations clearly showed that the goal was to eliminate minority groups.

The transfer of populations was halted by the outbreak of WW1 in 1914, but refugees continued to roam the Balkan area as the new states attempted to achieve national cohesion, rid themselves of minorities, and add territory. This process was revisited in multicultural Yugoslavia in the 1990s, as some of its newly sovereign component parts engaged in "ethnic cleansing" and strove to establish the largest possible national boundaries. As Marrus argues in The Unwanted, the growth of the modern nation-state resulted in the expulsion of groups who did not fit the definition of "nationals".

The concepts of the Greeks' Megali Idea and Ataturk's modern Turkish state, as well as World War I and nationalism, caused additional large-scale population displacement. The Megali Idea, or "Great Idea", was the dream of the re-establishment of a Hellenic Kingdom that would include all of the territory that had previously been part of the Byzantine Empire. Greeks saw as inevitable the recovery of the capital of Byzantium and metropolis of the Greek Orthodox Church, Constantinople, where many educated, rich, and powerful Greeks still lived. This nationalistic desire to expand the Greek territory to include all ethnic Greeks, including the millions living in Asia Minor, brought Greece into direct conflict with Turkey ${ }^{4}$.

13 Turkish harassment of ethnically Greek villages and cities in Western Anatolia during WW1, and the conscription of able-bodied ethnically Greek men into Turkish labor battalions ${ }^{5}$ increased Greek desires to unite the ethnically Greek areas within Turkey with mainland Greece. So fervently desired, Enosis-Union-had recently been achieved with several eastern Aegean islands, including Chios in $1912^{6}$.

With backing from Great Britain, France, and Italy, Greece invaded the Asia Minor port of Smyrna, called Izmir by the Turks, in 1919 in an attempt to annex the parts of Turkey that were substantially ethnically Greek. The Greek forces did well at first, advancing within forty miles of Ankara; however, foreign support dried up and the mainland Greeks, weary of decades of war, voted out the pro-war government. In 1921 Turkish forces under Ataturk were finally able to halt the Greek army and by 1922 the Greeks were in panic-stricken retreat ${ }^{7}$. In September, Turkish armies broke into Smyrna looking for revenge. Hundreds of thousands of Greek refugees had gathered there, hoping for transportation out of Turkey. Tens of thousands escaped, but tens of thousands more were killed or captured ${ }^{8}$. Henry Morgenthau, chairman of the League of Nations Greek Refugee Settlement Commission, estimated that 750000 refugees escaped from Smyrna during the "catastrophe". Many of these displaced persons sailed to nearby Aegean islands in small caiques and hundreds of thousands were transported to Athens, where Morgenthau witnessed their arrival :

The condition of these people upon their arrival in Greece was pitiable beyond description. They had been herded upon every kind of craft that could float, crowded so densely on board that in many cases they had only room to stand on deck. They were exposed alternately to the blistering sun and cold rain of variable September and October. In one case, which I myself beheld, seven thousand people were packed into a vessel that would have been crowded with a load of two thousand. In this and many other cases there was neither food to eat nor water to drink, and in numerous instances the ships were buffeted about for several days at 
sea before their wretched human cargo could be brought to land. Typhoid and smallpox swept through the ships. Lice infested everyone. Babes were born on board. Men and women went insane. Some leaped overboard to end their miseries in the sea. Those who survived were landed without shelter upon the open beach, loaded with filth, racked by fever, without blankets or even warm clothing, without food and without money.

Besides these horrors the refugees endured every form of sorrow-the loss of husbands by wives, loss of wives by husbands, loss of children by death or straying, all manners of illnesses 9 .

As Giannuli points out ${ }^{10}$, the abandonment of their wealth, necessitated by the hasty departure, impoverished the refugees and seriously impaired their ability to overcome hardships, as well as making a long-term detrimental impact on their financial and social status.

The disarray of the evacuation led to deliberate mistreatment of the refugees by some other Greeks. Greek sailors on the refugee ships charged for relief supplies and many people were unable to pay for provisions. This practice increased the mortality aboard the ships ${ }^{11}$. The report of the High Commission for Refugees of the League of Nations deplored the conditions of poverty of the refugees from the coastal areas of Anatolia ${ }^{12}$.

Following their enforced exodus, many refugees expected to be allowed to return to their homes; however, the 1923 Treaty of Lausanne, the Convention for the Exchange of Population between Greece and Turkey, put an end to their hopes of returning to their homes. Expectation of financial reimbursement for property abandoned in Anatolia was also futile. Some, such as Greek political historian A. A. Pallis, thought that the compulsory exchange of population was advantageous :

Thus the exchange of populations, by regrouping the various frontiers of the states to which they racially belonged, has undoubtedly contributed to no small degree, to the final elimination (italics mine) of what had, from all time been the principal cause of friction and conflict in the Balkans. ${ }^{13}$

Desired by the Turkish government to prevent further problems from any minorities, the cleansing of Anatolia of ethnic groups, including the Orthodox Greeks, resulted in over one million Asia Minor Greek refugees pouring into Greece during 1922 and 1923. The Treaty of Lausanne, which ended the Greek-Turkish War of 1919-1922, set the conditions for population exchange and recompense for property lost. This treaty, ratified and carried out by the League of Nations, was the first of its kind: internationally negotiated and sanctioned compulsory exchange of minorities. Both sides utilized the Treaty of Lausanne to rid themselves of unwanted minorities. Turkey attempted to banish all non-Muslim elements, while Greece used the Treaty to Hellenize Epirus by expelling Albanians, Macedonia by expelling Bulgarians, and Thessaloniki by expelling Ladino-speakers. Some Anatolian Greek refugees were given property abandoned by the groups expelled from Greece, but generally compensation was not adequate to prevent widespread poverty.

19 The experience of being prosfyges (lit. fugitives) was devastating for those involved. The Anatolian refugees were mostly women, children, and old men, as men between the ages of 18 and 45 had been forced into labor battalions, marched into the interior of Turkey and put to work rebuilding towns and factories destroyed during the war. The refugees had few resources and little economic opportunity. Impoverished by years of warfare, Greece had a population of just over 5 million at the time; the difficulty of absorbing an estimated 1,2 million Anatolian Greeks, while expelling 356000 Turks, 
overwhelmed the economic resources of the country. Malaria, typhoid, and dysentery were epidemic among the refugees. According to a League of Nations source, mortality rates among the new arrivals climbed at one point to 45 percent $^{14}$.

\section{Refugees on Chios}

Today, many of the survivors of the flight from Western Anatolia still live on the Eastern Aegean island of Chios, where I have been doing research since 1989. The events of the "Greek Catastrophe"-and especially of 1922 when the Turkish army broke into Smyrna, massacred large numbers of people, set the city ablaze, and destroyed it- are the defining moments of their lives and their memories remain vivid and compelling. Thousands managed to escape on boats and many ended up on Chios, the closest large Greek island.

\section{Social Production of Asia Minor Identity}

21 Although they have been living in Greece for over a quarter of a century, these people feel themselves, as Anatolians, to be different. They have constructed an enduring identity based on the memory of their origins. One 80-year-old refugee woman on Chios told me that «When we left Anatolia we were like the leaves from the trees when the wind takes them away and they blow right and left without knowing where they are going ». The refugees were no longer attached to their land, and only by producing a group identity could they feel grounded.

A complex array of factors has helped to create the separate identity of the Mikrasiates. Shared stories of harrowing escapes by boat from Smyrna or other coastal locations have created a sense of family survival against great odds. Relative material and economic deprivation, contrasting with memories of former wealth and large estates in Anatolia, have made them want to keep the past alive. The refugee families view themselves as more cultured, gentler, and "more kind," as one 88-year-old refugee woman on Chios explained. They brought with them their opinion of the superiority of their traditions and this belief gave them resilience.

Refugees preferred to marry other refugees. As another woman explained, Anatolians marry Anatolians, so that « the people from Smyrna would keep the customs that they had there ». When pressed to explain further, she responded simply, "It is necessary for us ». This desire to keep the customs of Anatolia reflects of the two branches of Greeks that were formed at the time of the Greek Independence Movement of 1822-1833.

The Greeks that became independent from the Ottoman Empire looked to Western Europe for their frame of reference and to the classical past for inspiration. But the Greeks that remained a part of the Ottoman Empire looked to Byzantium for their grounding. Constantinople represented the center of their social and religious world. Many Greeks were influential, wealthy and powerful in the Ottoman Empire. Both rich and poor believed in their cultural preeminence. In Turkey this belief in their distinction as a group was reinforced by their upholding of the traditions of Christianity, thus emphasizing their separateness. Orthodox Christianity gave them their primary identity within the Ottoman Empire. They had had a degree of self-rule granted to them by the Sublime Porte and had lived in relative harmony for over 400 
years with the Turks as well as with Armenians and other minorities. Some Anatolian Greeks had been driven from their homes when the Ottoman Empire joined Germany in WW1, but they had been able to return at the end of the war.

The Ionian coast, where most of the refugees on Chios are from, was wealthy from agriculture-figs, grapes, and tobacco-and from commerce. Cities such as Smyrna and Constantinople were major cosmopolitan centers; Smyrna was the primary port of the eastern Mediterranean. Once the refugees recovered from their most desperate situation, they were disappointed with the lack of sophistication of small provincial towns such as Chios city, and even of Athens and Thessaloniki. Never rich, mainland Greece had been impoverished by years of warfare : the Balkan Wars 1912-1913; World War 1, which Greece entered in 1917; and the Greco-Turkish war of 1919-1922. The refugees formed derogatory opinions about the lack of sophistication of the local Greeks and felt themselves to be more cultured. Refugees saw themselves as the successors to the rich traditions of Byzantium.

\section{Memories of Anatolia}

As prosfyges they were in a state of dependence, but as Mikrasiates they felt that they had a superior cultural endowment from the Byzantine heritage of their place of origin. The years of marginality, both social and political, reinforced their sense of separation.

Several aspects of refugee life served to give this group a sense of belonging, of preserving identity. Of these, with its strong Byzantine traditions, the Greek Orthodox religion is especially important to the people from Asia Minor. With its emphasis on miracles, Greek Orthodoxy is a unifying belief system for the Mikrasiates on Chios. For instance, there was a church dedicated to Agio Charalambo in the town of Chezme on the Asia Minor coast, just opposite Chios. Refugees collected money out of their earnings to build a new church for Agio Charalambo in a refugee quarter in Chios. They told me that their saint comes out during the night, performing miracles and walking around the church.

Other stories of miracles include one in which an icon of the Panagia-the Virgin Maryprotected some girls in Smyrna hiding under a bed from being seen by Turkish soldiers. This icon is now in a refugee church in Chios. Churches in the refugee quarters of Chios have many icons and relics brought from towns in Turkey. Belief in their miraculous powers reinforced the feeling of continuity with the past and imparted to the refugees the conviction that saints were and are active in their survival as a people.

Shared memories have allowed the refugees to reconstruct their lives, if not just as they had been, at least with continuity. As Renée Hirschon points out in her groundbreaking study of a refugee area near Athens, Heirs of the Greek Catastrophe ${ }^{15}$, Orthodox Christianity emphasizes the importance of memory. Every day has a Saint's name attached to honor the memory of that saint. Rituals to remember the dead abound in Orthodox tradition. Memory is power in Orthodoxy and tradition gives the past its meaning. Through ritual, Greek religion links the dead of preceding generations with the living and the unborn. Orthodoxy emphasizes the mystery of regeneration, immortality, and continuity with the past. With very few exceptions, all Greeks are Orthodox, but their religion has special power for the refugees, as memory gives the Mikrasiates the means to construct their social identity. 
Preservation of memory is located in other places besides the church. Community centers in refugee areas have musical programs of rembetika, the music that grew out of the experiences of the refugees, and programs with films and old photos of Asia Minor. I have attended these programs and noticed an almost equal number of young, middleaged and elderly people there.

In addition, voluntary associations, such as the Centre for Asia Minor Studies, the Pontian Society, and the Union of Smyrniots, have been formed to help preserve the memories. Publication of books by the Centre for Asia Minor Studies, such as the beautifully produced Refugee Greece ${ }^{16}$, and of the Centre's Bulletin promote the retention of memories of the lost homeland.

2 Museums also reinforce the social production of refugee identity. One refugee quarter on Chios built its own museum by collecting a large amount of memorabilia, photographs and artifacts from families. Relics include items such as leaves from a tree in a garden in Anatolia; refugees had snatched the leaves as the family fled the Turkish army. The sense of longing for the lost homeland is pervasive. The programs, museums and churches give meaning to their journey as refugees, as have the cherished family photographs, which give recollections substance.

Generally, individuals use family photographs to document family history. Mikrasiates use family photographs as cultural documentation of memory as well. The visual images establish the reality of the past; they are used as proof of the truth of the existence of the family in another place, at another time. Photographs of the family home in Anatolia, Smyrna as it was before 1922, and ancestors with the now elderly refugees as children, grouped together in comfortable surroundings, freeze time and reinforce the image and remembrance of the lost world.

4 The visual heritage of the personal record of the family, together with published or exhibited photographs, allows children and grandchildren to enter the past and share the experiences of life long ago. Photographs are used as catalysts for the conversation that passes on the memories of grandparents to younger generations.

Visual presentation enables the refugees to display, recount, and recall the cultural heritage of the family. As the family and group history is retold, it is preserved and enhanced. The photographs are a personal message from the past, providing visual reinforcement of the assertion that because of their cultural heritage their family is different from other Greeks. The past exists forever, preserved in prints, which bear witness to the reality of memories of life in Anatolia, where the traditions of Byzantium lingered on ${ }^{17}$.

36 The construction of refugee identity is sustained and nourished by reminiscences, which provide a chronicle of the ethnohistory of the Mikrasiates. Recollection documents the past and the past is interpreted through the remembered experience. Memory does not exist in a vacuum : the retelling of personal and public experience that augments its meaning surrounds it. Through the interpretation of memory, the past is reified and validated.

\section{Conclusion}

Memory reinforces the social production of a group with a separate identity. When Mikrasiates recount family history, their experience reinforces a sense of community 
and shared history. The memories illustrate the narrative of diaspora-the shared history of the refugees.

The story told by the Asia Minor refugees follows the master narrative of diaspora: they were forced to abandon their homeland, the lost paradise. They yearn for reunion, but reunion is impossible. In this politics of identity, the remembered past and the lost paradise-real or imagined-are used to create commonalities and community.

\section{NOTES}

1. Hirschon (Renée), Heirs of the Greek Catastrophe: The Social Life of Asia Minor Refugees in Piraeus, Oxford: Clarendon Press, 1989, p. 2.

2. See Augustinos (Gerasimos), The Greeks of Asia Minor: Confession, Community, and Ethnicity in the Nineteenth Century, Kent, Ohio : Kent State University Press, 1992 ; Kitromilides (Paschalis M.), Alexandris (Alexis), "Ethnic Survival, Nationalism and Forced Migration", Bulletin of the Centre for Asia Minor Studies. V, 1984-1985 ; McCarthy (Justin), Muslims and Minorities : The Population of Ottoman Anatolia at the End of the Empire, New York : New York University Press, 1983, for descriptions of Greeks as an ethnic minority under Ottoman rule.

3. Marrus (Michael R.), The Unwanted: European Refugees in the Twentieth Century, Oxford: Oxford University Press, 1985, p. 48.

4. See Tsolainos (Kyriakos P.), "Greek Irredentism », Annals of the American Academy of Political and Social Sciences, CVIII, 1923, for a contemporary, personal view of the Megali Idea.

5. See Tanc (Barbaros), «Where local trumps national », this volume, for one example.

6. See Smith (Michael Llewellyn), Ionian Vision: Greece in Asia Minor 1919-1922, London: Allen Lane, 1973, for a discussion of Enosis.

7. See Smith (Michael Llewellyn), op. cit., Pallis (A. A.), Greece's Anatolian Venture-and After, London : Meuthun \& Co. Ltd., 1937, for a description of the campaign.

8. See Houspian (Marjorie), The Smyrna Affair, New York: Harcourt Brace Jovanovich Inc., 1966, for a well-researched description; Oeconomos (Lysimachos), The Martyrdom of Smyrna and Eastern Christendom, London: George Allen \& Unwin Ltd., 1922, for an emotional report ; and Horton (George), The Blight of Asia, Indianapolis : Bobbs Merrill, 1926, for the first-hand account of the American consul in Smyrna.

9. Morganthau (Henry), I Was Sent to Athens, Garden City, New York : Doubleday, Doran \& Co., Inc., 1929, pp. 48-49.

10. Giannuli (Dimitra), «Greeks or "Strangers at Home": The Experiences of Ottoman Greek Refugees during their Exodus to Greece, 1922-1923 », Journal of Modern Greek Studies, 13, 1995.

11. Ibid ; League of Nations, Greek Refugee Settlement, Geneva : League of Nations, 1926.

12. See Ladas (Stephen P.), The Exchange of Minorities, Bulgaria, Greece and Turkey, New York : Macmillian, 1932, for a description.

13. Pallis (A. A.), op. cit., p. 169.

14. See Pentzopoulos (Dimitri), The Balkan Exchange of Minorities and Its Impact upon Greece, Paris : Mouton \& Co., 1962, and Eddy (Charles B.), Greece and the Greek Refugees, London: George Allen \& Unwin Ltd., 1931 for a full description.

15. Hirschon (Renée), op. cit. 
16. Yiannakopoulos (Georgios A.), ed., Refugee Greece, Athens : Centre for Asia Minor Studies, 1992.

17. James (Alice), Smith (Barbara), « The Mirror of Their Past: Greek Refugee Photographs and Memories of Anatolia », Visual Anthropology Review, 16, 2000.

INDEX

Mots-clés : Réfugiés

Index géographique : Asie mineure, Grèce, Turquie

\section{AUTEUR}

\section{ALICE JAMES}

Professor of Anthropology, Department of Sociology and Anthropology, Shippensburg University. 